\title{
A nest of European Golden Plover Pluvialis apricaria with all blue eggs lacking cryptic mottling
}

Ett bo av ljungpipare Pluvialis apricaria med helt blå ägg utan kamouflageteckning

\author{
SÖREN SVENSSON
}

While surveying birds within a study plot on alpine mores in southern Swedish Lapland, I found a nest of the Golden Plover Pluvialis apricaria. It contained four eggs that were all bright blue without cryptic colouration. The location was at about $65^{\circ} 50^{\prime} \mathrm{N}$ and $16^{\circ} 20^{\prime} \mathrm{E}$, and the elevation about 800 meters. The nest was found at noon on 27 June 2014. The Golden Plover is common in the area and hundreds of nests have been found by our research group during more than fifty years. None of these has been reported to contain eggs without
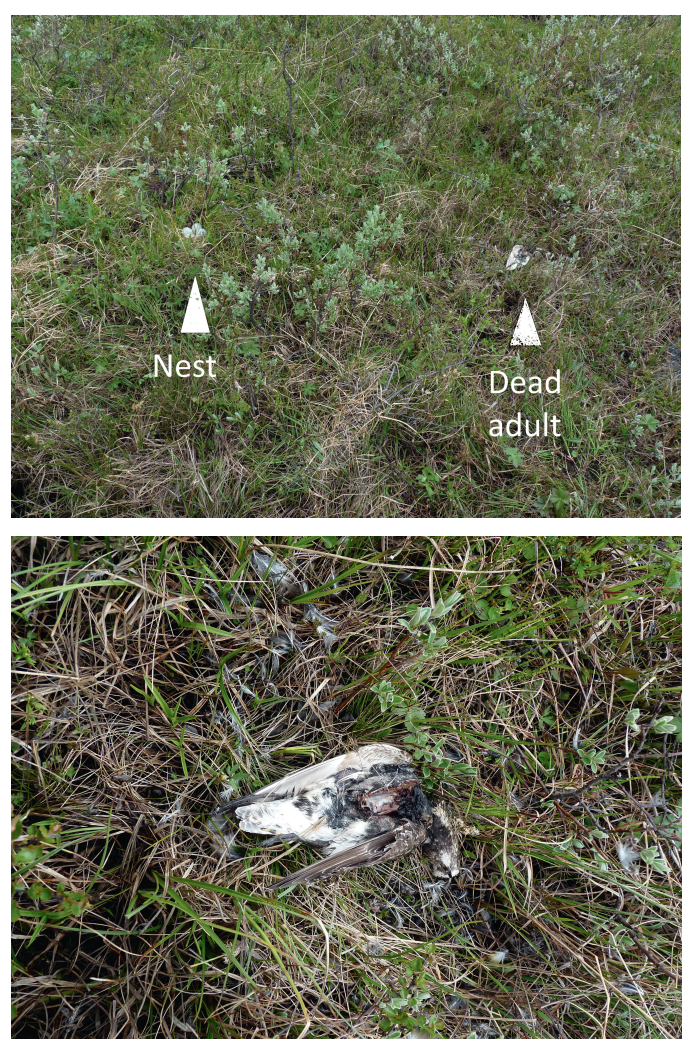

normal cryptic speckling. An incubating plover sits hard and when a nest is found it is most often because the bird is flushed or observed at close distance to sneak off the nest.

In the case reported here I discovered the nest at a distance of at least ten to fifteen meters because I got sight of the eggs in spite of having my attention primarily on counting birds in general. They were shiny blue or turquoise (Figure 1), very conspicuous and hence easily drew attention at some distance, which normal cryptic eggs never do.
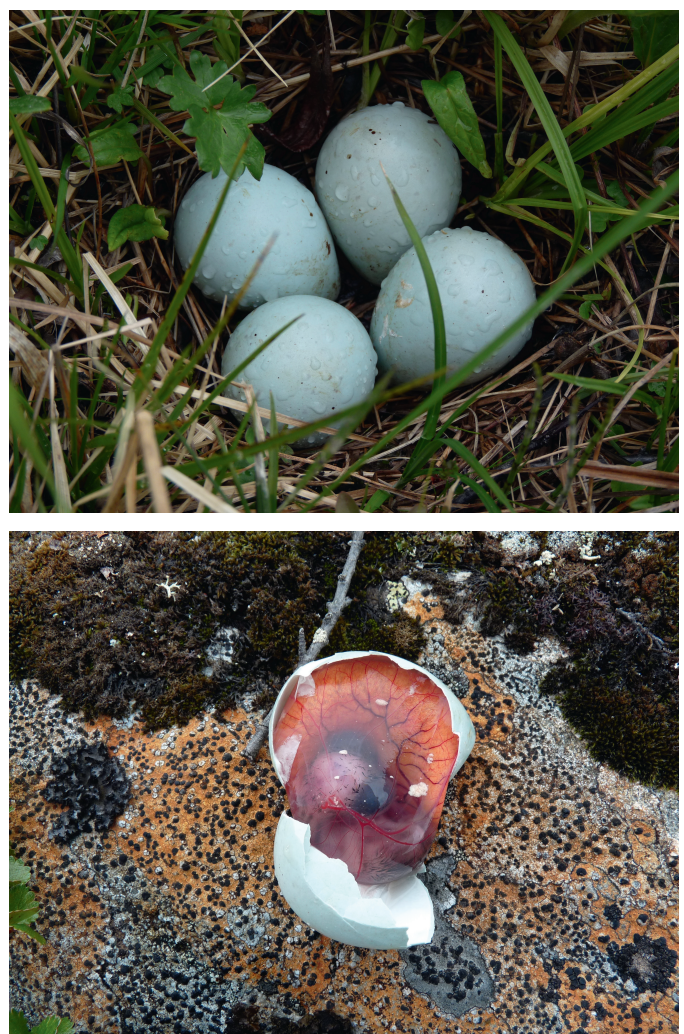

Figure 1. Golden Plover nest with blue eggs without cryptic coloration that were easily detected at some distance. One of the parents lay dead and partly consumed by a predator near the nest. The eggs contained embryos that seemed to have developed normally until death.

Bo av ljungpipare med rent blå ägg utan skyddsteckning. De kunde lätt upptäckas på avstånd. En av föräldrarna låg död nära boet, delvis uppäten av någon predator. Äggen innehöll embryon som verkade ha utvecklats normalt tills de dog. 
When approaching the nest, I found a dead adult about two meters from it. The eggs lay undisturbed in the nest cup with no sign of damage, indicating that the predator was most probably a bird, Gyrfalcon being the most likely guess. The eggs were wet because of rain and somewhat dirty, probably because of some fighting before the kill, indicated also by faeces on the eggs. It was a rather fresh kill, although the body as well as the eggs had cooled. The bird was probably the male as it is almost exclusively males that incubate during day-time (Whittingham et al. 2000), but as I did not examine the bird carefully it could have been the female as well. The eggs contained embryos that had been incubated about a week.

I have not approached any egg-collecting museums but one, the Swedish Museum of Natural History at Stockholm. In its collection of about 80 clutches there are no eggs similar to the ones I found (Ulf Johansson in litt.). I have not consulted the oological literature at large, only Rosenius (1937). He does not mention any aberrantly coloured eggs for the Golden Plover among 190 eggs. Whatever the exact proportion, non-cryptic eggs must be rare. And it seems that aberrant egg colouration of other kinds and in other species is also very rare, for example albinistic eggs which are only rarely found in otherwise normally coloured clutches (Gross 1968).

If a bird egg is coloured the pigment is either biliverdin or protoporphyrin or a combination of both (Kennedy \& Vevers 1976). These two pigments are the only ones that have been found in any appreciable amount in bird eggshells. Consequently, these two pigments are responsible for the seemingly limitless variation of colours and patterns. Reflectance, concentration and a few other factors modify and enhance the variation created by the pigments alone. It is perhaps difficult to believe that two single pigments can be responsible for the enormous variation. However, in a recent study Hanley et al. (2015) demonstrated by a colour mixing model that this is actually possible. It has even been suggested that the same pigments may have governed the colouring of dinosaur eggs (Wienmann et al. 2015). From that it can perhaps be concluded that biliverdin and protoporphyrin were fixed as the both necessary and sufficient egg pigments at a very early stage of reptile-bird evolution. Interestingly, as mollusc shells are calcareous and have a great colourful variation - both these properties the same as in birds - it has been found that only protoporphyrin, not biliverdin, is responsible for the colour variation among molluscs (Verdes et al. 2015).

Biliverdin is the pigment that gives the blue to green colour (as in Starling) and protoporphyrin the brown to rusty colour (as in Peregine Falcon). This means that the shells of the Golden Plover eggs that I found had only the biliverdin pigment. There was no sign of the typical brown dots, patches or streaks of normal eggs. The black dots that are seen in the photographs were plant fragments. Regrettably, I did not collect any shell fragments. One might think that the absence of speckling in my case was caused by a defective outer shell layer, but this cannot be the case as protoporphyrin is mainly located in the deeper parts of the shell (Samiullah \& Roberts 2013) and should have been visible if present at all. The content of the eggs including the embryos looked healthy so it is unlikely that any excess desiccation had occurred, indicating that the shell functioned as it should. This is in accordance with what Deeming (2011) found in his review of water loss in relation to egg colour; there was no effect of either the degree of speckling or the intensity of background colour.

It is well known that cryptic eggs increase nest survival among ground-nesting birds such as waders, for example in Western Snowy Plover (Colwell et al. 2011) and Moutain Plover (Skrade \& Dinsmore 2013). Some cost is of course involved in laying eggs with cryptic colour as protoporphyrin and biliverdin must be synthesised in the shell gland for each egg, but it is likely that the increased reproductive success outweighs this cost (Wang et al. 2009). It is not possible to determine what may have happened in the present case, for example if absence of cryptic coloration of the eggs played any role for predation to occur.

\section{Acknowledgment}

I thank Ulf Johansson at the Swedish Museum of Natural History at Stockholm for checking the egg collection for aberrant Golden Plover eggs.

\section{References}

Colwell, M.A., Meyer, J.J., Hardy, M.A., Mcallister, S.E., Transou, A.N., Levalley, R.R. \& Dinsmore, S.J. 2011. Western Snowy Plovers Charadrius alexandrinus nivosus select nesting substrates that enhance egg crypsis and improve nest survival. Ibis 153(2): 303-311. DOI:10.1111/ j.1474-919X.2011.01100.x

Deeming, D.C. 2011. A review of the relationship between eggshell colour and water vapour conductance. Avian Biology Research 4(4):224-230. 
Gross, A.O. 1968. Albinistic eggs (white eggs) of some North American birds. Bird-Banding 34(1): 1-6.

Hanley, D., Grim, T., Cassey, P. \& Hauber, M.E. 2015. Not so colourful after all: eggshell pigments constrain avian eggshell colour space. Biology Letters 11: 20150087. http://dx.doi.org/10.1098/rsbl.2015.0087

Kennedy, G.Y. \& Vevers, H.G. 1976. A survey of avian eggshell pigments. Comparative Biochemistry and Physiology 55B: 117-123.

Rosenius, P. 1937. Sveriges fåglar och fågelbon. Volume 4. Gleerups, Lund.

Samiullah, S. \& Roberts, J.R. 2013. The location of protoporphyrin in the eggshell of brown-shelled eggs. Poultry Science 92(10): 2783-2788. doi: 10.3382/ps.2013-03051.

Skrade, P.D.B. \& Dinsmore, S.J. 2013. Egg crypsis in a ground-nesting shorebird influences nest survival. Ecosphere 4(12): 1-9. DOI:10.1890/ES13-00246.1

Verdes, A., Cho, W., Hossain, M., Brennan, P.L.R., Hanley, D., Grim, T., et al. (2015) Nature's Palette: Characterization of Shared Pigments in Colorful Avian and Mollusk Shells. PLoS ONE 10(12): e0143545. doi:10.1371/journal.pone.0143545

Wiemann, J., Yang, T., Sander, P.N.N., Schneider, M., Engeser, M., Kath-Schorr, S., Müller, C.E. \& Sander, P.M. 2015. The blue-green eggs of dinosaurs: How fossil metabolites provide insights into the evolution of bird reproduction. PeerJ PrePrints 3:e1323 https://doi.org/10.7287/ peerj.preprints.1080v1

\section{Sammanfattning}

När jag inventerade fåglar på fjällhed i södra Lappland påträffade jag den 27 juni 2014 ett bo av ljungpipare som innehöll fyra helt blå ägg. Fyndet gjordes sydost om Ammarnäs på en nivå om 800 meter. I Ammarnäs har hundratals ljungpiparbon påträffats under de mer än femtio år som jag forskat i området. Normalt trycker ljungpiparna hårt på äggen och bon upptäcks därför vanligen när den ruvande fågeln stöts från boet eller observeras smyga iväg. Ett bo utan ruvande fågel upptäcks nästan aldrig spontant eftersom äggen är så väl skyddsfärgade. Det bo som jag rapporterar om här upptäcktes redan på tio till femton metes håll tack vare de lysande blå äggen. Närmare boet upptäckte jag en av föräldrarna ligga död ett par meter från boet. Fågel var delvis uppäten, gissningsvis dödad av en jaktfalk. Bofyndet illustreras i Figur 1.

Äggen saknade alla fläckar, prickar och streck som normala ägg har. De svarta prickar som syns på fotot var växtfragment. Boet var intakt med det fanns avföring på äggen. Detta tillsammans med växtfragmenten kan tyda på att viss strid förekommit på marken. Ljungpiparen hade dödats ganska nyligen men så väl fågeln som äggen hade svalnat. Äggen innehöll embryon.

Jag har inte gått igenom några äggsamlingar på större museer. På Naturhistoriska riksmuseet i Stockholm har Ulf Johansson gått igenom samlingen och meddelat att inga avvikande ägg finns bland 80 kullar. Inte heller har jag konsulterat den oologiska litteraturen i stort, bara Rosenius (1937), som inte nämner något avvikande bland 190 studerade ägg.

Om ett fågelägg är färgat så är färgämnet antingen biliverdin eller protoporfyrin eller en kombination av båda. Dessa två pigment är de enda som förekommer i nämnvärd mängd i äggskal. Det är alltså dessa som skapar den till synes oändliga variation som fågelägg uppvisar. Det kan vara svårt att tro att bara två pigment kan skapa denna variation. Men i en nyligen publicerad studie har Hanley m.fl. (2015) visa att detta är fullt möjligt. I en annan studie har Wienmann m.fl. (2015) kommit fram till att äggen hos dinosaurier också bör ha färgats av samma pigment. Från detta kan man kanske dra slutsatsen att de två pigmenten fixerades som både nödvändiga och tillräckliga på ett mycket tidigt stadium i utvecklingslinjen mot reptiler och fåglar. En intressant detalj i sammanhanget är att mollusker, som likt fåglarna har färggranna kalkskal, endast använder protoporfyrin.

Biliverdin är färgämnet som ger gröna eller blå skal (som stare) och protoporfyrin brun eller rostaktig färg (som pilgrimsfalk). Det betyder att de blå äggen i ljungpiparens bo endast hade biliverdin. Äggens innehåll var färskt och utan skador, liksom embryona. Det tyder på att skalen fungerat som de skulle under ruvningen trots att de saknade protopofyrin. Detta stämmer med vad Deeming (2011) fann i en översikt av vattenförluster, nämligen att uttorkningen inte påverkades vare sig av grundfärgens intensitet eller av mängden fläckar.

Sören Svensson, Department of Biology, Biodiversity, Lund university, 22362 Lund, Sweden.

E-mail: Soren.Svensson@biol.lu.se 